\title{
Diagnostics and symptomatic treatment of non- keratinizing squamous cell metaplasia of the urinary bladder in children - own experience
}

\author{
Beata Jurkiewicz, Katarzyna Załęska-Oracka*, Joanna Samotyjek, Ewa Wajszczuk and Magdalena Szymanek-Szwed \\ Department of Pediatric Surgery and Pediatric Urology Centre of Postgraduate Medical Education, Children's Hospital in Dziekanów Leśny, Poland
}

\begin{abstract}
Background: In this article, authors present their own experience in diagnostics and treatment of non-keratinizing squamous cell metaplasia of the urothelium in pediatric patients. Squamous metaplasia is an abnormal replacement of urothelial epithelium of urinary bladder with non-keratinizing stratified squamous epithelium. It is mostly recognized in adult women in the post-menopausal period. There are only a few descriptions of the occurrence of squamous metaplasia in children in world literature.

Results: Research conducted by the authors included children hospitalized in the Surgery Department in the years 2005-2018. During this time metaplasia was diagnosed in 254 children - 248 girls and 6 boys aged from 1.5 to 17 years. The primary causes of hospitalization were non-specific abdominal pain, voiding disorders and recurrent urinary tract infections. In the studied cases, the most common symptoms of abnormal bladder function were: pollakiuria, difficulties in initiating micturition and urinary retention. Patients underwent many diagnostic procedures: clinical examination, general urinalysis, and urine culture, ultrasound of the urinary tract, cystoscopy, immunohistochemical, endocrinological and urodynamics examinations. Statistical analysis includes only children, who underwent cystoscopy together with biopsy and histopathological section, which indicated metaplasia of the urothelium. All patients were treated symptomatically.
\end{abstract}

Conclusion: Squamous metaplasia can occur in both children and adolescents. Symptomatic treatment improves the quality of patient's life. However, does not effect regression of metaplasia. In control cystoscopies, authors do not observe the improvement. The causal treatment will be possible after further and closer examination of the pathogenesis and etiology of changes in the urinary bladder.

\section{Introduction}

Squamous metaplasia is the transformation of normal urothelial epithelium to the stratified squamous non-keratinizing epithelium. The most common localizations of such changes are the triangle and neck of the bladder (Figures 1 and 2). Metaplasia of vesical mucosa usually occurs in adult women in the post-menopausal period. In the literature, this type of metaplastic changes has no risk of progression to neoplasia. The main reasons of the occurrence of metaplasia in adults introduced in literature are a malfunction of endocrine glands, chronic inflammations, Vitamin A deficiency, estrogens and progesterone deficiency, S. hameatobium, recurrent inflammations of the bladder, neurogenic bladder, post-surgery in the bladder region.

There are only a few articles in worldwide literature describing the occurrence of non-keratinizing squamous metaplasia of the bladder in the pediatric population [1-5]. In this article authors present cases of 254 children diagnosed with metaplasia, hospitalized in our Department in years 2005-2018 (Figure 3).

The main reasons for hospitalization were:

- recurrent infections of the urinary tract,

- erythrocyturia

- pollakiuria,

- dysuria,
- difficulties in initiating micturition

- urinary retention

- non-specific pain of the abdomen,

- pain during micturition, requiring analgesic treatment

The cause of abdominal pain in patients with metaplasia of urinary bladder is not fully understood. It may occur due to the damage of the glycosaminoglycans layer (GAG) of the urothelial epithelium. Damage of the protective layer causes leaking epithelium syndrome. It simplifies the migration of allergens, irritating chemicals, toxins, drugs and bacteria deeper in bladder tissues, and in result, causes painful bladder syndrome [6-8].

Some of the scientific reports show the co-existence of metaplasia in neurogenic bladders [9].

Patients diagnosed in our Department underwent diagnostic procedures, which revealed the metaplasia of the vesical urothelium.

*Correspondence to: Katarzyna Załęska-Oracka, Pediatric Surgery Ward, Children's Hospital in Dziekanów Leśny; Marii Konopnickiej 65, 05-092 Łomianki, Poland, Tel: +48 602608156; E-mail: k_zaleska@o2.pl

Key words: urothelium, metaplasia, cystoscopy, histopathology, immunology, children

Received: May 28, 2019; Accepted: June 14, 2019; Published: June 17, 2019 


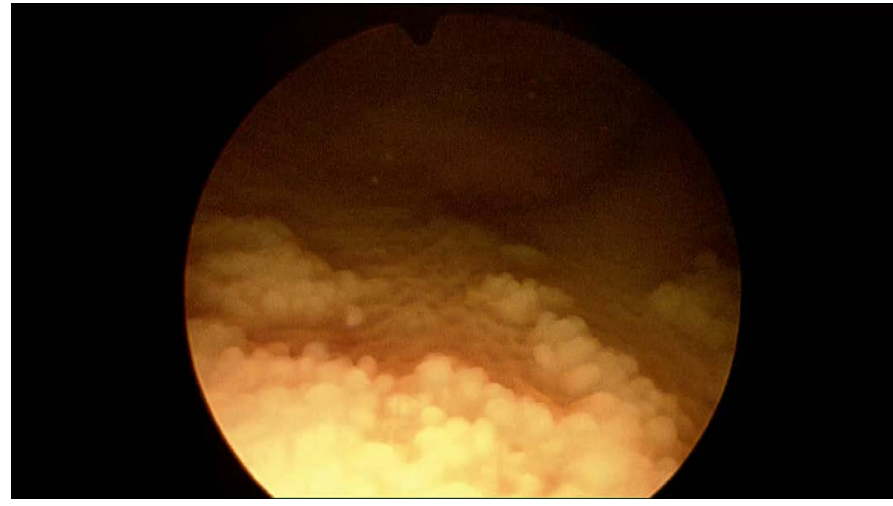

Figure 1. Squamous metaplasia of the bladder urothelium - cystoscopy picture.

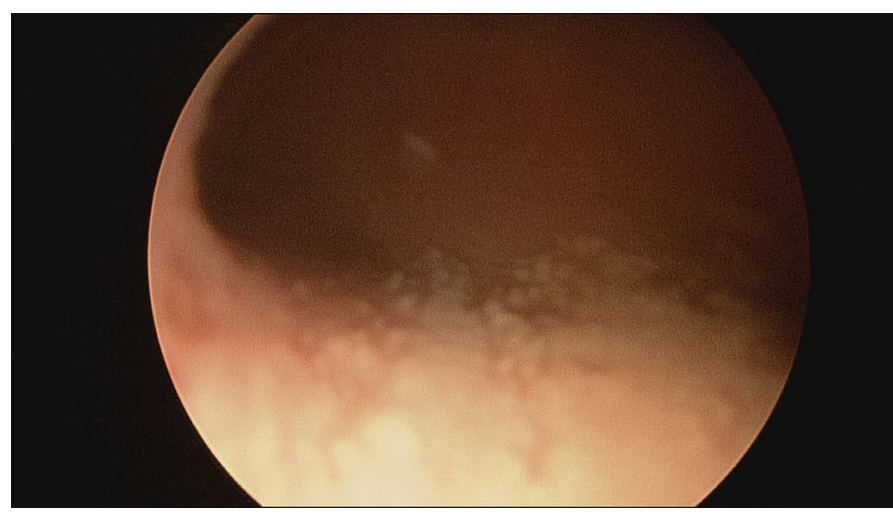

Figure 2. Squamous metaplasia of the bladder urothelium- cystoscopy picture.

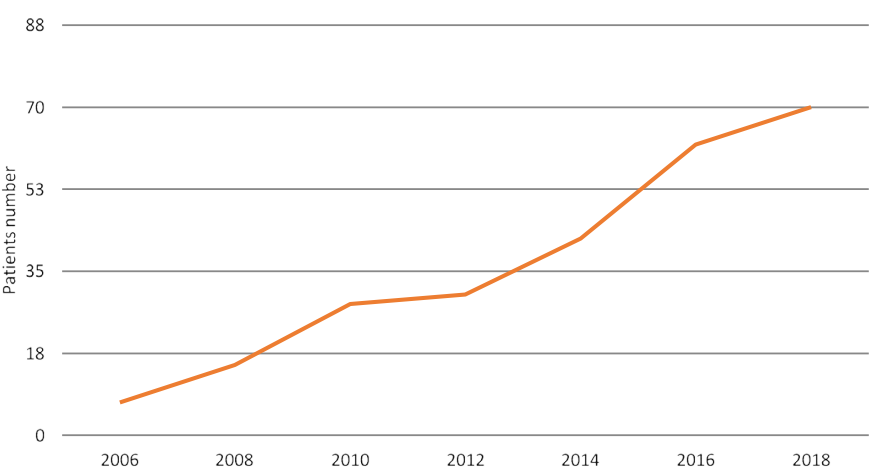

Figure 3. Number of patients per unit of time, showing all 254 patients between years 2005 to 2018 and growing trend of yearly morbidity.

The pathogenesis and etiology of metaplastic changes in the urinary bladder have not been fully understood. The symptomatic treatment improves the quality of patients' lives but does not affect the formation of metaplasia in the urinary bladder. There is a need for further research to find the causes of metaplasia. It would allow to implement appropriate treatment and eliminate metaplasia of the bladder region.

\section{Materials and methods}

In the period from 2005 to 2018 squamous metaplasia was diagnosed in 254 children - 248 girls and 6 boys - aged from 1.5 to 17 years (average 13,7 years) (Figures 4 and 5). In studied cases, the symptoms of abnormal bladder function were: pollakiuria, difficulties in initiating micturition, urinary retention due to detrusor muscle disability, abdominal pain and recurrent infections of the urinary tract.
Patients diagnosed in our Department were qualified for cystoscopy under short-term general anesthesia. In 35 (14\%) patients' squamous metaplasia was incidentally diagnosed during cystoscopy performed for treating urolithiasis or congenital defects of the lower urinary tract.

Only children who underwent cystoscopy together with biopsy and histopathology section examination, which indicated metaplasia of the urothelium, were included in a clinical trial. General urinalysis and urine culture, ultrasound of the urinary tract, urodynamic examination was performed. To resolve the possibility of development of the proliferative process in urinary bladder all specimen underwent immunohistochemical tests. Endocrinological and immunological blood tests were performed in $87(34,2 \%)$ of the patients - only teenagers after puberty.

All patients diagnosed with metaplasia underwent control cystoscopy with biopsy once a year to check the progression of the disease.

Patients with acute infections of the urinary tract were treated with antibiotics from the Cephalosporin group and irrigation of bladder with $2 \%$ Gentamycin solution. In the case of recurrent infections, long-term anti-bacterial treatment with furazidinum, trimethoprim/

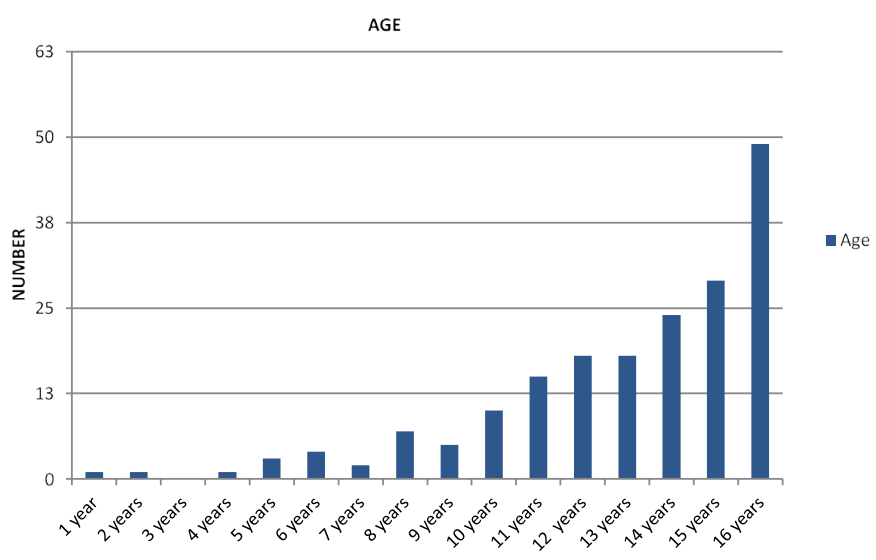

Figure 4. Number of patients in age groups - newly diagnosed.

\section{Amount}

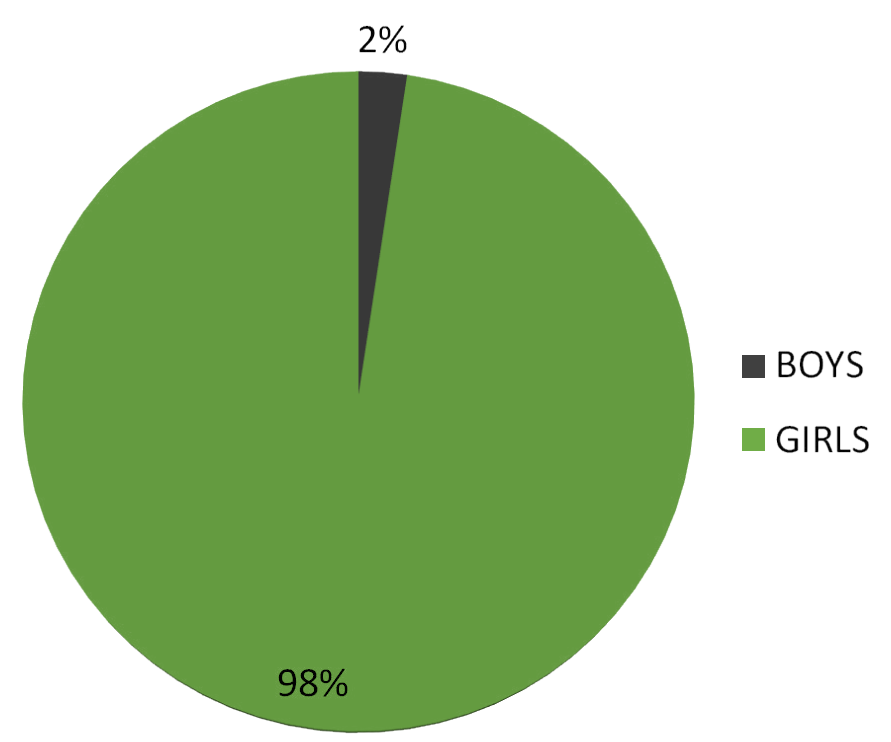

Figure 4. Number of patients in age groups - newly diagnosed. 
sulfamethoxazole, and trimethoprim was used. Immunomodulating treatment with Uro-Vaxom, Thym-Uvocal, and supplementation of Vitamin A was introduced. Additionally, patients with abnormal function of the bladder, revealed in the urodynamic examination, were treated with biofeedback and oxybutynin or solifenacin. Moreover, the diet excluding citrus fruits, pepper, chili, hot spices, cranberry, Vitamin $\mathrm{C}$ and other products causing acidification of urine were recommended, to reduce the irritation of the bladder tissues. According to articles showing the positive impact of intravesical hyaluronic acid instillation in adult patients with interstitial cystitis, authors decided to use this type of treatment in two of female patients suffering from painful bladder syndrome [10-12].

In all performed cystoscopies macroscopic changes of the bladder urothelium characteristic for non-keratinizing metaplasia were revealed - white, fluffy surfaces in bladder triangle and neck. In some patient's epithelium changes exceeded triangle - those patients presented severe symptoms.

Histological examinations of bladder specimens showed atypical cellular nuclei.

Immunohistochemical tests included caspase, cytokeratin AE-1/ $\mathrm{AE}-3$, and Ki67 antigen showed that metaplastic epithelium is in fact stratified squamous epithelium typical for all stages of development [13].

The p53 protein test confirmed its low-level, which means the reduced possibility of neoplastic transformation.

All patients underwent urodynamic examination, which revealed the abnormal function of the urinary bladder, particularly the detrusor muscle hyperactivity and reduced bladder capacity [14-15].

In girls, who underwent endocrinological examination, the low level of progesterone in the luteal phase was found, along with the menstrual disorder.

\section{Immunological tests revealed:}

- decrease of immunoregulatory functions of lymphocytes $\mathrm{T}$ quantitative and functional deficit of $\mathrm{T}$ lymphocyte population, decrease in TCD4/TCD8 ratio, decrease in mitigate replay, SAT activity deficiency, decrease in IL-10 formation;

- increase of immunogenic activity of monocytes - hyperactivity of monocytes LM, the deficit of anti-inflammatory influences of IL-1ra;

- the increased pro-inflammatory immunogenic activity of the immune system.

The examination showed, that immunology has a great influence on the formation of metaplasia of the vesical mucosa, but further and closer examination is needed.

\section{Discussion}

Pathogenesis of metaplasia of vesical mucosa is not fully understood. Most of the clinical trial programs concentrate on hormonal changes in women in the post-menopausal period. Those trials do not concern children in pubertal age. Commonly used therapy in adults like anti-inflammatory, Vitamin A, oxybutynin, bladder irrigation with gentamicin solution, does not give predictive results in the pediatric population. It requires searching for alternative therapies, which might be used to treat both children and adolescents.

Organism homeostasis depends on proper function and cooperation of nervous, endocrine and immunological systems [16] (Figure 6).

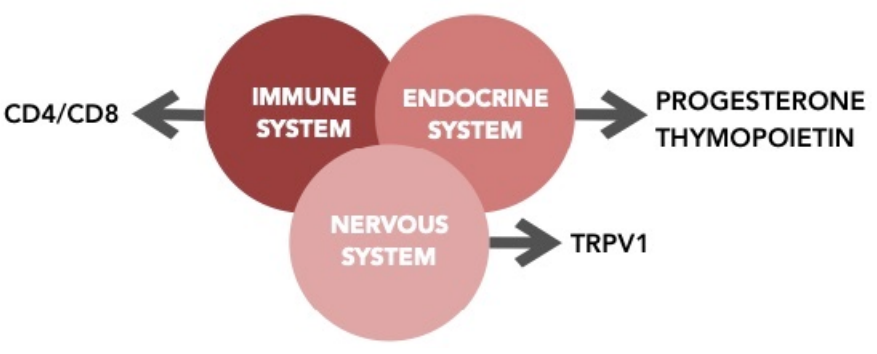

Figure 6. Organism homeostasis

Endocrinological changes, observed in an analyzed group, may be considered as the main reason for the occurrence of non-keratinizing metaplasia changes in children.

Moreover, in all patients' metaplastic changes occurred only in the bladder triangle. The trigonal originate from different germ layer than the ventral bladder wall, and its' development and function depend on sex hormones. That even stronger confirms the theory of the dependence of metaplasia formation on the endocrine system.

In the world literature, there are many publications about the impact of environment pollution on endocrinological changes in children and adolescents. The level of environmental pollution has an impact on hormonal changes in children.

EEDs is a group of environmental endocrine disruptors that may affect the human endocrine system and produce adverse neurological and immune effects.

Endocrine disruptors may be found in many everyday productsincluding plastic bottles, metal food cans, detergents, flame retardants, food, toys, cosmetics, and pesticides [17]. Among all EEDs bisphenol $\mathrm{A}$ is one of the highest volume chemicals in use today [18]. BPA has been shown more recently to stimulate biological responses at very low concentrations and has been demonstrated to be as potent as estradiol in some of its effect [19-22].

The group most exposed to the harmful influence of BPA are fetuses, babies, women, and men [23]. One of the trials showed the BPA level $<0,026-2,569 \mathrm{ng} / \mathrm{ml}$ in umbilical cord blood, which confirms the risk of exposure of unborn children on this compound [24].

The BPA penetrates to the human body by skin, with food and air. For all age groups, the main factor of exposure to BPA is canned food [25].

Researches prove that precocious puberty may be related to exposure of BPA. Durmaz, et al. proved a statistically higher level of BPA in the urine of girls with precocious puberty in comparison to control group and suggest that higher level of BPA may be one of the risk factors of ICCP [26].

Authors extend the hypothesis that a high level of BPA may cause metaplastic changes in the bladder region.

\section{Conclusion}

The cause of the formation of squamous metaplasia in the bladder region is still unclear. Previous attempts of finding the causes of the transformation of urothelial epithelium to non-keratinizing squamous metaplasia in the bladder region have failed. However, the authors suggest that one of the main factors affecting epithelial change may be progressive environmental pollution. Especially EEDs and among them bisphenol A, which affect the hormonal system. This hypothesis 
requires a further and closer examination of the pathogenesis and etiology of changes in the urinary bladder.

\section{References}

1. Jurkiewicz B, Matuszewski L, Bokwa T, Gut G, Rybak D (2006) Bladder Squamous Metaplasia of the Urothelium - introductory report. Urol Int 77: 46-9. [Crossref]

2. Jurkiewicz B, Bokwa T, Matuszewski L, Gut G, Rybak D, et al. (2005) Metaplazja płaskonabłonkowa nabłonka urotelialnego błony śluzowej pęcherza moczowego doniesienie wstępne. Paediatrics and Family Medicine 1: 266-271.

3. Jurkiewicz B, Wozniewicz B, Bokwa T (2006) Metaplazja błony śluzowej pęcherza moczowego. Paediatrics and Family Medicine 2: 100-104

4. Murali K Ankem, Aron B Grotas, Benjamin Shurtleff, David DiPiazza, Nicola Barnard, et al. (2002) Nonkeratinizing Squamous Metaplasia of the Bladder in Children. Infect Urol 15: 22-25.

5. Beata Jurkiewicz, Tomasz Zabkowski (2014) Nonkeratinised Squamous Metaplasia of the Urinary Bladder in Children: A Report of Case Experiences. Biomed Res Int. 2014: 936970. [Crossref]

6. Radziszewski P, Gugala A, Borkowski T, et al. (2007) Skuteczność kwasu hialuronowego w łagodzeniu objawów zespołu bolesnego pęcherza. Urologia Polska 60 .

7. French LM, Bhambore N (2011) Interstitial Cystitis/ Painful Bladder Syndrome.” Am Fam Physician 83: 1175-1181. [Crossref]

8. Gamper M, Viereck V, Ebhart J, Binder J, Moll C, et al. (2013) Local immune response in bladder pain syndrome/ interstitial cystitis ESSIC type 3C. Int Urogynecol $J 24$ : 2049-2057. [Crossref]

9. Schleger TA, Grady R, Mills SE, Hendley JO (2004) Bladder epithelium is abnormal in patients with neurogenic bladder due to myelomeningocele. Spinal Cord 42: 163-168. [Crossref]

10. NeÄmark BA (2003) Treatment of persistent dysuria in women. Urologiia 3: 16-20. [Crossref]

11. Cruz F, Dambros M, Naber KG (2009) Recurrent Urinary Tract Infections: Uro-Vaxom, a New Alternative. European Urology Supplements 8: 762-768.

12. Chancellor MB, Yoshimura N (2004) Treatment of interstitial cystitis. Urology 63: 8592. [Crossref]
13. Dlugosz M, Bar K (2005) Analiza nienowotworowych zmian patologicznych wykrytych w czasie biopsji blony sluzowej pecherza moczowego. Urologia Polska 58:1.

14. Rechberger T, Wróbel A (2009) Patofizjologia zaburzen mikcji - wysilkowe nietrzymanie moczu. Nietrzymanie moczu pod red. T Rechbergera 4 : 37-49.

15. Andrzej Prajzner (2008) Techniki badan urodynamicznych: pulapki techniczne i trudnosci interpretacyjne wyników - czesc I. Urologia Polska 61: 3.

16. Smith EM1, Blalock JE (1988) A molecular basis for interactions between the immune and neuroendocrine systems. Int $J$ Neurosci 38: 455-464. [Crossref]

17. Wlodarczyk E (2015) Occurrence of bisphenol A and its effects on the human body Arch Physiother Glob Res 19: 13-26.

18. Global Industry Analysis Inc.

19. Alonso-Magdalena P, Laribi O, Ropero AB, Fuentes E, Ripoll C, et al. (2005) Low doses of bisphenol $\mathrm{A}$ and diethylstilbestrol impair $\mathrm{Ca} 2+$ signals in pancreatic alpha-cells trough a nonclassical membrane estrogen receptor within intact islets of Langerhans. Environ Health Prespect 113: 969-77. [Crossref]

20. Alonso-Magdalena P, Ropero AB, Carrera MP, Cederroth CR, Baquié M, et al. (2008) Pancreatic insulin content regulation by the estrogen receptor ER alpha. PLoS One 3:1-11. [Crossref]

21. Hugo ER, Brandebourg TD, Woo JG, Loftus J, Alexander JW, et al. (2008) Bisphenol A at environmentally relevant doses inhibits adiponectin release from human adipose tissue explants and adipocytes. Environ Health Prespect 116: 1642-1647. [Crossref]

22. Zsarnovszky A1, Le HH, Wang HS, Belcher SM (2005) Ontogeny of rapid estrogenmediated extracellular signal-regulated kinase signaling in the rat cerebellar cortex: potent nongenomic agonist and endocrine disrupting activity of the xenoestrogen bisphenol A. Endocrinology 146: 5388-5396. [Crossref]

23. Sekizawa J1 (2008) Low-dose effects of bisphenol A: a serious threat to human health? J Toxicol Sci 33: 389-403. [Crossref]

24. Claudia B, Laurence C, Jean-Pierre C, Karl-H E, Paul F, et al. (2015) Scientific opinion on the risk to public health related to the presence of bisphenol A (BPA) in foodstuffs: Part II - Toxicological assessment and risk characterization. EFSA J 13: 1-621.

25. Salachan PV, Teja DNC, Rajan AP (2014) How safe are our babies? An in-sight on effect of bisphenol A (BPA) on development. J Drug Deliv 4: 92-96.

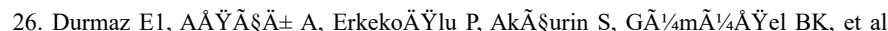
(2014) Urinary bisphenol a levels in girls with idiopathic central precocious puberty. $J$ Clin Res Pediatr Endocrinol 6: 16-21. [Crossref]

Copyright: (C2019 Jurkiewicz B. This is an open-access article distributed under the terms of the Creative Commons Attribution License, which permits unrestricted use, distribution, and reproduction in any medium, provided the original author and source are credited. 